\title{
Analisis Penyusunan Anggaran Dan Realisasinya Sebagai Alat Penilaian Kinerja Perusahaan Pada Pt. Len Railway Systems (LRS) Kantor Cabang Kebumen
}

\author{
Eko Aprilawati ${ }^{1 *}$,Wakhid Yuliyanto ${ }^{2}$ \\ ${ }^{1}$ Akuntansi, Politeknik Dharma Patria Kebumen, Indonesia, 54316 \\ ${ }^{2}$ Akuntansi, Politeknik Dharma Patria Kebumen, Indonesia, 54316 \\ *Email: aprilawatie@gmail.com,wyuliyanto45@gmail.com \\ Doi : https://doi.org/10.37339/jurnal e-bis.v4i2.387
}

Info Artikel

Diterima :

20-11-2020

Diperbaiki :

26-11-2020

Disetujui :

27-11-2020

\begin{abstract}
ABSTRAK
PT. Len Raiway Systems (LRS) merupakan perusahaan yang bergerak di bidang elektronika khususnya dalam bidang perkeretaapian dibawah naungan PT. Len Industri. Penyusunan anggaran pada PT. LRS untuk mengetahui dasar belanja perusahaan sesuai dengan perencanaan kebutuhan perusahaan. Penggunaan anggaran diharapkan akan sesuai dengan yang telah dibuat, namun pada kenyataannya banyak realisasi anggaran yang melebihi target yang sudah ditetapkan. Sehingga pelaksanaan realisasi kurang efisien. Penyusunan anggaran yang seharusnya sebagai dasar dalam belanja perusahaan justru berbeda pada relisasinya. Penelitian ini menggunakan analisis varian dimana persentase selisih anggaran yang dibuat dengan realisasi anggaran menjadi dasar dalam menganalisis penyusunan anggaran. Penilian ini menghasilkan analisis varian pada biaya material sebesar $4 \%$, biaya instalasi sebesar $6 \%$, biaya pekerjaan non instalasi $0 \%$, dan biaya pekerjaan item baru sebesar $20 \%$. Analisis varians dihitung dengan membandingkan selisih anggaran yang telah dibuat dengan realisasinya kemudian diubah menjadi persentase. Kinerja perusahaan dalam menganggarkan biaya dan merealisasikannya yang dianalisis menggunakan analisis varian dinilai tidak efektif dan tidak efisien dimana banyak dana yang kurang tepat terserap. Sehingga terdapat selisih yang cukup besar pada anggaran yang dibuat dan pada realisasi anggaran.
\end{abstract}

Kata Kunci : Anggaran, Realisasi, Analisis Varians.

\section{ABSTRACT}

$P T$. Len Raiway Systems (LRS) is a company engaged in the electronics sector, especially in the railroad sector under the auspices of PT. Len Industri. Budgeting at PT. LRS is used as a basis relating to company spending in accordance with the company's planning needs. The use of the budget is expected to be in accordance with the preparation of the budget that has been made, but in fact many budget realization exceeds the predetermined target. This makes the implementation of budget realization inefficient. Budgeting, which should be used as a benchmark for company spending, is not in accordance with the relationship. This study uses analysis of variance in which the percentage difference between budget and realization becomes the basis for analyzing budget preparation. This assessment resulted in a variant analysis on material costs of 4\%, installation costs of $6 \%$, non-installation work costs of $0 \%$, and new item work costs of $20 \%$. Analysis of variance is calculated by comparing the budget made with its realization which is then converted into a percentage. The company's performance in budgeting costs and realizing it, which is analyzed using analysis of variance, is considered less effective and efficient, where many funds are not properly absorbed. So that there is a sizable difference between budget and realization.

Keywords: Budget, Realization, Variance Analysis

\begin{tabular}{lll}
\hline Alamat Korespondensi & Jl. Letnan Jenderal Suprapto No.73 Kebumen, Jawa Tengah, Indonesia 55431 \\
\hline
\end{tabular}




\section{PENDAHULUAN}

Penyusunan anggaran merupakan kegiatan penting sebuah manajemen perusahaan. Hal tersebut dikarenakan menjadi kegiatan awal sebuah proyek perusahaan yang akan menentukan perkembangan serta pertumbuhan perusahaan tersebut. Anggaran kegiatan di dalam perusahaan pada periode tertentu dan biasanya bisa berupa uang, maupun dalam satuan barang.

Anggaran merupakan pedoman untuk melaksanakan operasi, kriteria untuk memonitor dan mengendalikan aktifitas, dan pengesahan tindakan. Blocher dkk (2012:448). Anggaran dalam merencanakan target yang harus dipenuhi oleh perusahaan dan sebagai tolak ukur alokasi dana perusahaan yang disetujui pimpinan untuk dibelanjakan. Pada anggaran yang sudah digunakan maka akan dicatat dalam laporan realisasi. Laporan realisasi anggaran merupakan sebuah data keuangan yang lebih dahulu dihasilkan sebelum kemudian dijadikan bahan dalam pembuatan laporan keuangan perusahaan.

Penyusunan anggaran harus berdasar pada target pengeluaran dan pada hasil yang telah diperoleh. Pada saat merealisasikan anggaran harus mengukur tingkat efisiensi dan efektifitas sehingga penyusunan anggaran sesuai dengan yang ditetapkan. Efisien diukur dengan membandingkan antara input (misalnya dana) yang digunakan dengan keluaran (output) yang diperoleh. Sedangkan efektifitas diukur dengan menilai apakah keluaran dapat berfungsi sebagaimana diharapkan sehingga mendatangkan hasil (outcome) yang diinginkan. Nasution, dkk (2020: 54)

PT. Len Raiway Systems (LRS) merupakan perusahaan yang bergerak di bidang elektronika khususnya dalam bidang perkeretaapian dibawah naungan PT. Len Industri. Penyusunan anggaran pada PT. LRS digunakan sebagai dasar belanja perusahaan sesuai dengan perencanaan kebutuhan perusahaan. Penggunaan anggaran diharapkan sesuai dengan anggaran yang telah dibuat, namun pada kenyataannya banyak realisasi anggaran yang melebihi target yang sudah ditetapkan. Sehingga pelaksanaan realisasi anggaran kurang efisien. Anggaran yang sudah disusun seharusnya dijadikan dasar dalam belanja perusahaan justru berbeda dengan relisasinya.

Berdasarkan penelitian Agustyani (2015) yang membahas tentang Analisis Anggaran Dan Realisasi Angggaran Pada Dinas Pendapatan Dan Pengelolaan Keuangan (Dppk) Kabupaten Bandung.Anggaran menjadi penghubung antara sumber daya keuangan dengan perilaku manusia dalam rangka pencapaian tujuan keuangan.Pada sektor swasta anggaran merupakan bagian dari rahasia perusahaan yang tertutup untuk publik, namun sebaliknya pada sektor publik anggaran justru harus diinformasikan kepada publik untuk dikritik, distribusikan dan diberi masukan.

\section{METODE}

A. Metode Penelitian

Metode penyusun yang digunakan yaitu metode Penelitian deskriptif dengan metode analisis kuantitatif. Metode analisa deskriptif yaitu metode untuk menganalisis data dengan cara mendeskripsikan atau menggambarkan data yang telah terkumpul sebagaimana adanya tanpa bermaksud membuat kesimpulan yang berlaku untuk umum atau generalisasi.

Metode analisis dekriptif mempelajari norma-norma atau standar-standar, sehingga metode analisis penelitian deskriptif disebut survey normative. Metode analisis deskriptif dapat meneliti masalah normative bersama-sama dengan masalah status dan sekaligus juga membuat 
perbandingan-perbandingan antar fenomena. Presfektif waktu penyusun dalam metode analisis deskriptif adalah waktu sekarang atau sekurang-kurangnya jangka waktu yang masih terjangkau oleh ingatan responden.

Sedangkan metode analisis pendekatan kuantitatif yaitu proses menemukan pengetahuan yang menggunakan data berupa angka sebagai alat menemukan keterangan-keterangan mengenai apa yang ingin kita ketahui.

Dalam metode ini penyusun mengumpulkan data historis dan mengamati secara seksama mengenai aspek-aspek tertentu yang berkaitan dengan masalah yang sedang diteliti oleh penyusun sehingga akan memperoleh data-data yang dapat mendukung penyusunan laporan penelitian. Data-data yang telah diperoleh akan diproses dan dianalisis dengan menggunakan dasar teori yang telah dipelajari sehingga memperoleh gambaran mengenai objek tersebut dan dapat ditarik kesimpulan mengenai masalah yang diteliti.

Analisis variabel adalah suatu atribut sifat atau nilai dari suatu Orang, objek, atau kegiatanya yang mempunyai versi tertentu yang ditetapkan oleh peneliti untuk dipelajari dan kemudian ditarik kesimpulanya. Hubungan antara antar variabel dalam penelitian terdapat 2 yaitu variabel independen (variabel bebas) adalah variabel bebas yang mempengaruhi atau yang menjadi sebab timbulnya variabel dependen (variabel terikat). Sedangkan variabel dependen (variabel terkait) adalah variabel yang dipengaruhi atau menjadi akibat, karena adanya variabel independen (variabel bebas).

Variabel-variabel yang digunakan dalam penelitian ini adalah sebagai berikut:

1. Efektivitas penyusunan dana anggaran yang disusun oleh menejemen perusahaan.

2. Anggaran yang terealisasi pada setiap bagian pengeluaran pada proyek perusahaan.

3. Variabel Operasional yaitu cara untuk mengukur konsep dan bagaimana caranya konsep tersebut diukur sehingga terdapat variabel-variabel yang akan saling mempengaruhi dan dipengaruhi, yaitu variabel yang menyebabkan timbulnya masalah lain.

4. Kondisi dan situasi yang tergantung oleh variabel lain. Tabel 3.1 Kriteria Efisiensi Kinerja Keuangan :

Dengan Kriteria Persentasi Kinerja Keuangan apabila :

$>100 \%$ keatas $=$ Tidak Efisien

$90 \%-100 \%=$ Kurang Efisien

$80 \%-90 \%=$ Cukup Efisien

$60 \%-80 \%=$ Efisien

$<60 \%=$ Sangat Efisien

B. Sumber Data dan Jenis Data

1. Sumber Data

a. Data Primer

Agung (2012:60) analisis data primer yaitu data yang diperoleh atau dikumpulkan oleh peneliti atau lembaga tertentu langsung dari sumbernya, dicatat dan diamati untuk pertama kalinya dan hasilnya digunakan langsung oleh peneliti atau lembaga itu sendiri untuk memecahkan persoalan yang akan dicari jawabannya. Penyusun penelitian ini menggunakan analisis data primer yang diperoleh melalui hasil pengamatan dan wawancara dengan Staff Keuangan PT. Len Railway System (LRS) Kantor Cabang Kebumen.

b. Data Sekunder 
Agung (2012:60) analisis data sekunder yaitu data yang diperoleh atau dikumpulkan oleh orang lain atau lembaga tertentu. Penyusun penelitian ini menggunakan analisis data sekunder dengan melihat Laporan Realisasi Anggaran Pendapatan dan Belanja.

2. Jenis Data

Analisis yang digunakan adalah analisis penelitian kualitatif yaitu mendeskripsikan data keuangan berupa laporan realisasi anggaran PT. Len Railway System (LRS) Kantor Cabang Kebumen dan menjelaskan data keuangan tersebut secara kualitatif. Penelitian ini dilakukan dengan metode penelitian lapangan (fiendl research) terjun langsung ke PT. Len Railway System (LRS) Kantor Cabang Kebumen.

Metode ini bertujuan untuk mengumpulkan data keuangan dan menyajikan, serta menganalisis data keuangan yang jelas untuk bisa ditarik kesimpulan.

\section{Teknik Pengumpulan Data}

Juliandi, dkk (2014:85) teknik analisis data berarti menginterpretasikan data-data yang telah dikumpulkan dari lapangan dan telah diolah sehingga menghasilkan informasi tertentu. Analisis dengan metode deskriptif kualitatif yaitu mengembangkan teori yang telah dibangun dan yang sudah didapatkan di lapangan dengan melakukan penjelajahan, kemudian dilakukan pengumpulan data sampai mendalam, mulai dari observasi hingga penyusunan laporan yang dilakukan dengan cara :

1. Bagaimana penyusunan anggaran PT LRS pada tahun 2017 sampai 2019?

Anggaran disusun oleh pihak manajemen perusahaan dengan masa periode proyek.

2. Apa dasar manajemen perusahaan menyusun anggaran proyek?

Dasar manajemen menyusun anggaran proyek adalah anggaran proyek sebelumnya dengan menyesuaikan kebutuhan untuk periode proyek.

3. Apakah anggaran sebelumnya sudah sesuai dengan realisasi yang sudah ditargetkan?

Sejauh ini anggaran yang disusun masih terdapat selisih jauh dengan realisasinya.

Teknik analisis untuk menjawab rumusan masalah yang kedua dilakukan dengan mengumpulkan data keuangan dari laporan realisasi anggaran PT. Len Railway System (LRS) Kantor Cabang Kebumen.

\section{HASIL DAN PEMBAHASAN}

Prosedur Penyusunan Anggaran PT Len Railway Systems

\section{A. Penentuan Pedoman Anggaran}

Penentuan pedoman anggaran keuangan dilakukan dengan melakukan kegiatan menyusun anggaran dalam waktu setahun kedepan dan dalam pelaksanaan penyusunannya dipersiapkan dalam beberapa bulan atau minggu.

Dalam penyusunan anggaran sebuah perusahaan biasanya dilakukan atau dilaksanakan oleh manajemen puncak atau top management. Dalam sistem managemen puncak terdapat dua metode kegiatan dalam penyusunan anggarannya, diantaranya:

1. Penetapan rencana besar bagi perusahaan, yang mana kegiatan ini menyusun rencana tujuan atau peluang dan menganalisa asumsi asumsi kedepan pada sebuah perusahaan yang menjadikan dasar menyusun anggaran tersebut.

2. Pembentukan panitia penyusun anggaran. 


\section{○ Eko Aprilawati dan Wakhid Yuliyanto}

\section{B. Persiapan Anggaran Keuangan}

Sebuah Perusahaan membutuhkan waktu dalam mempersiapkan Anggaran Keuangan pada perusahaan tersebut, yang mana penyusunan pada anggaran perusahaan tersebut, tidak hanya dilakukan oleh tenaga penyusun anggaran yang telah disusun perusahaan akan tetapi juga membutuhkan kerjasama dengan tenaga bagian keuangan serta tenaga bagian umum dalam perusahaan tersebut.

Selanjutnya ketiga tenaga kerja diberikan wewenang untuk dapat menyusun anggaran keuangan sesuai kebutuhan dan aktifitas kegiatan perusahaan, diantaranya :

1. Penyusunan anggaran biaya sewa site office

2. Penyusunan anggaran persediaan barang dan peralatan kerja di perusahaan

3. Penyusunan anggaran biaya sewa gudang untuk perusahaan

4. Penyusunan anggaran upah kerja

5. Penyusunan anggaran mobilisasi dan logistic

Kegiatan penyusunan anggaran tersebut ditujukan untuk dapat menjalankan kegiatan perencanaan atas kebutuhan keuangan yang akan dibelanjakan dan diperoleh oleh sebuah perusahaan. Dan menjadi sebuah manfaat bagi perusahaan dari adanya kegiatan penyusunan anggaran tersebut.

\section{Penentuan Anggaran Perusahaan}

Tahapan selanjutnya adalah Penentuan Anggaran perusahaan, dan pada tahapan ini terdiri dari beberapa tahap dalam menentukan anggaran perusahaan, yaitu :

1. Perundingan antara masing - masing bidang tenaga kerja guna untuk menyesuaikan kebutuhan akhir anggaran yang direncanakan;

2. Koordinasi, evaluasi dan verifikasi komponen anggaran perusahaan;

3. Pengesahan anggaran perusahaan serta pendistribusiannya sesuai dengan perencanaan.

\section{Pelaksanaan Anggaran}

Pelaksanaan Anggaran merupakan tahapan keempat dari beberapa tahapan sebelumnya, pada proses akhir dari beberapa tahapan dalam penyusunan anggaran perusahaan hingga akhirnya disetujui dan menjadi keputusan tunggal.

Setelah tahapan ini dilakukan, manager mempunyai kewajiban untuk melaporkan hasil akhir dari penyusunan anggaran perusahaan kepada direksi perusahaan. Demikian ini menjadi alur terkhir dari tahapan tahapan penyusunan dan penerapan anggaran

Anggaran Biaya dan Realisasi Tahun 2019 Sumber : Data Diolah, 2020 menunjukkan laporan anggaran dan realisasi PT. Len Railway System (LRS) Kantor Cabang Kebumen tahun 2019. Pada laporan anggaran dan realisasi diatas dapat diketahui jumlah anggaran pada masingmasing sub pekerjaan. Setelah mengetahui jumlah anggarannya maka terdapat jumlah realisasi pada tiap sub pekerjaan.

Jumlah realisasi dan anggaran pada sub pekerjaan tidak semua memiliki jumlah yang sama. Ternyata ada selisih yang menjadikan anggaran tidak terserap secara menyeluruh. Simpangan dalam bentuk persen menunjukkan prosentase dari besarnya realisasi dana terhadap anggaran yang telah disusun.

Ketika realisasi dan anggaran memiliki jumlah yang sama maka prosentasenya akan menunjukkan jumlah sebesar $100 \%$. Artinya seluruh dana yang dianggarkan semuanya 
terealisasi. Namun tidak sedikit juga prosentase yang menunjukkan angka kurang atau lebih dari $100 \%$ tergantung dengan jumlah realisasi dari anggaran yang ditetapkan.

Analisis Varians terhadap Penyusunan Anggaran dan Realisasi di PT. Len Railway Systems (LRS) Kantor Cabang Kebumen Analisis varians terhadap Penyusunan Anggaran dan Realisasi Rumus Varians adalah sebagai berikut: Varians Dalam pelaksanaan kegiatannya PT. Len Railway Systems (LRS) Kantor Cabang Kebumen belum melakukan analisis varians biaya. Perusahaan hanya menghitung selisih dari anggaran dan realisasinya.

Untuk itu analisis varians perlu dilakukan untuk mengetahui prosentase selisih sebuah anggaran dan realisasinya. Penyusun membuat hasil analisis yang didapat selama melakukan penelitian pada PT. Len Railway Systems (LRS) Kantor Cabang Kebumen.

Analisis Varian Anggaran dan Realisasi Tahun 2019 Sumber : Data Diolah, 2020 Berdasarkan tabel terdapat perbedaan dari table sebelumnya, tabel tersebut merupakan hasil analisis yang penulis susun. Dengan tabel tersebut diharapkan dapat mempermudah sistem penyusunan anggaran biaya pada PT. Len Railway Systems (LRS) pada tabel 4.2 diatas. Penjelasan tabel tersebut dapat dirincikan sebagai berikut:

1. Material Anggaran biaya material lebih kecil dibandingkan jumlah biaya yang direalisasikan. Varian tersebut merupakan varian unfavorable (tidak menguntungkan) dimana realisasi anggaran yang lebih besar dibandingkan dengan anggaran yang telah disusun. Maka akan dikatakan kurang efisien, dimana anggaran yang telah disusun tidak sesuai dengan biaya yang dikeluarkan. Dan dana yang harus dikeluarkan oleh perusahaan lebih besar dibandingkan dengan anggaran yang telah dibuat.

2. Instalasi (Termasuk material instalasi dan jasa instalasi) Anggaran untuk biaya instalasi lebih besar dari realisasi. Varian tersebut merupakan varian favorable (menguntungkan) dimana realisasi lebih kecil dibandingkan dengan yang telah disusun. Dalam hal ini perusahaan mendapatkan keuntungan dari biaya yang telah dianggarkan. Namun, menurut penyusun kinerja perusahaan dalam merealisasikan angggaran kurang maksimal dimana anggaran yang terealisasi dinilai lebih sedikit dari seluruh anggaran yang dibuat.

3. Anggaran biaya pekerjaan Non-Instalasi pekerjaan non-instalasi sama dengan realisasi. Untuk varian anggarannya sebesar Rp 0,- dimana tidak ada selisih antara anggaran dan realisasi. Artinya seluruh anggaran yang dibuat terealisasi dengan sub pekerjaan dibidang pekerjaan non-instalasi. Analisis yang penulis dapat dengan data yang dibuat PT. LRS yaitu terjadi analisis varian sebesar $\mathrm{Rp}$ 0,-. Varian tersebut merupakan varian favorable (menguntungkan) dimana realisasi anggaran lebih kecil dibandingkan yang telah disusun. Adapun varian diatas bila dipresentasekan, maka hasilnya adalah sebesar $0 \%$. Kinerja perusahaan dalam menyusun anggaran sudah tepat sehingga dana dapat diserap $100 \%$ pada saat realisasi.

4. Pekerjaan Item Baru biaya anggarannya lebih kecil dibandingkan realisasinya. Varian tersebut merupakan varian unfavorable (tidak menguntungkan) dimana anggaran realisasi lebih besar dari anggaran yang telah disusun. Dikatakan kurang efisien, dimana pembuatan anggaran berbeda dengan biaya yang dikeluarkan. Dan dana lebih besar yang harus dikeluarkan oleh perusahaan dibandingkan yang sudah dibuat.

Permasalahan Anggaran dan Realisasi di PT. Len Railway Systems (LRS) Kantor Cabang Kebumen :

a. Penyusunan anggaran belum efektif dimana terdapat selisih jumlah biaya yang dianggarkan 
yang cukup jauh dari realisasinya.

b. Selisih anggaran dan realisasi dapat menimbulkan kerugian bagi perusahaan.

Penyelesaian Masalah :

a. Manajemen perusahaan harus memikirkan secara matang dan memiliki dasar perhitungan sesuai dilapangan.

b. Penggunaan dana pada saat realisasi harus tepat sasaran sehingga selisih yang timbul tidak terlalu jauh.

\section{KESIMPULAN}

Kesimpulan penyusun atas penelitian yang sudah dilakukan yang berjudul Analaisis Penyusunan Anggaran dan Realisasinya sebagai Alat Penilaian Kinerja Perusahaan pada PT. Len Railway Systems (LRS) Kantor Cabang Kebumen antara lain :

A. PT. Len Railway Systems (LRS) merupakan perusahaan yang bergerak di bidang elektronika khususnya dalam bidang perkeretaapian dibawah naungan PT. Len Industri. Penyusunan anggaran yang baik bagi PT. Len Railway Systems yaitu dengan menetapkan jumlah anggaran berdasarkan penyusunan anggaran proyek sebelumnya serta survei kebutuhan dan harga di lapangan.

Penyusunan anggaran juga dibuat semaksimal mungkin agar tidak terdapat selisih jauh dan mengalami kerugian antara anggaran dan realisasi.

B. Penyusun membantu PT. Len Railway Systems (LRS) Kantor Cabang Kebumen dalam menganalisis anggaran pada periode tahun 2017 sampai tahun 2019.

Penyusunan ini menggunakan analisis varians dimana perhitungan dihasilkan dari selisih anggaran dan realisasi kemudian di ubah dalam bentuk prosentase. Hasil dari prosentase tersebut akan menghasilkan nilai terhadap anggaran yang direalisasi dengan simbol U (Unfavorable) dan F (Favorable).

C. Analisis penyusunan anggaran pada PT. Len Railway Systems (LRS) Kantor Cabang Kebumen menghasilkan suatu analisis varians mengenai penyusunan anggaran.

Dapat disimpulkan bahwa dana yang dianggarkan tidak semuanya terealisasi. Bahkan terdapat beberapa biaya yang tidak terealisasi sampai melebihi dari anggaran yang dibuat. Namun terdapat beberapa biaya yang sesuai antara anggaran dan realisasi. Hal tersebut menjadikan perusahaan dinilai kurang efektif dalam merealisasikan anggaran.

D. Pada penelitian diatas disimpulkan kinerja perusahaan dalam menganggarkan biaya dan merealisasikannya yang dianalisis menggunakan analisis varian dinilai tidak efektif dan efisien dimana banyak dana yang kurang tepat terserap.

Penyelesaian pada masalah tersebut yaitu saat penyusunan anggaran seharusnya mempertimbangkan selisih yang terjadi agar tidak terlampau jauh. Cadangan dana harus dimiliki oleh Manajemen perusahaan untuk menutupi dana yang terdapat selisih cukup jauh. Sehingga tidak ada kerugian yang banyak.

Apabila penyusunan anggaran dan realisasinya sudah efektif maka akan mendapatkan kepercayaan pada proyek-proyek selanjutnya. 


\section{REFERENSI}

Abdul Hafiz, Tanjung. 2009. Akuntansi Pemerintahan Daerah. Jakarta. Alfabeta.

Agung, Anak Agung Putu. 2012. Metodologi Penelitian Bisnis. Malang: Universitas Brawijaya Press.

Armanto Witjaksono SE, AK, MM. 2013.Akuntansi Biaya. Yogyakarta: Graha Ilmu.

Blocher, dkk. 2012. Manajemen Biaya Penekanan Strategis Edisi 3 Buku 1. Jakarta: Salemba Empat.

Deddi Nordiawan, Iswahyudi, Maulidah Rahmawati.2009. Akuntansi Pemerintahan. Jakarta.

Ahmad, Firdaus Dunia dan Wasilah Abdullah. 2012. Akuntansi Biaya.Jakarta: Salemba Empat.

Hansen dan Mowen. 2016. Akuntansi Manajerial terjemahan. Jakarta:Salemba Empat.

Herlianto, Didit. 2011. Teknik Penyusunan Anggaran Operasional Perusahaan. Yogyakarta : Gosyen Publishing.

Hery. 2015. Pengantar Akuntansi. Jakarta : Grasindo

James M. Reeve. 2013. Pengantar Akuntansi Adaptasi Indonesia. Jakarta: Salemba Empat.

Juliandi, Azuar. Dkk. 2014. Metodologi Penelitian Bisnis Konsep dan Aplikasi. Medan: UMSU PRESS.

Nafarin, M. 2013. Penganggaran Perusahaan. Edisi ketigaBuku 1. Jakarta : Salemba Empat.

Nasution, Dito Aditia Darma. Dkk. 2020. Bimbingan Teknis Peningkatan Kualitas Laporan Keuangan pada Pemerintah Kota Tanjung Balai (Kecamatan Datuk Bandar). Ponorogo: Uwais Inspirasi Indonesia.

Muindro Renyowijoyo. 2010. Akuntansi Sektor Publik Organisasi Non Laba. Jakarta: Mitra Wacana Media.

Purwaji, dkk. 2016. Pengantar Akuntansi 1. Edisi 2. Jakarta: Salemba Empat.

Rudianto. 2009. Pengantar akuntansi. Jakarta: Penerbit Erlangga. 